\title{
Trade Potential of Climate Smart Goods of Vietnam: An Application of Gravity Model
}

\author{
Vu Van TrungA, Nguyen Anh ThuA* \\ Received: June 28, 2015 | Revised: September 22, 2015 | Accepted: March 16, 2016
}

\begin{abstract}
This paper examines the trade potential of climate smart goods (CSG) of Vietnam. In particular, the study employs gravity model with panel data for bilateral trade between Vietnam and its 45 partners from 2002 to 2013 with an objective of identifying the determinants explaining Vietnam's trade of climate smart products. The estimation results reveal that economic size, market size, distance, real exchange rate, border, and the quality of infrastructure of both Vietnam and its trading partners play a major role in bilateral trade of CSG. Additionally, the paper applies the method using speed of convergence and the estimated gravity equation to answer whether Vietnam has fully realized the potential trade of CSG. Accordingly, Vietnam has strong opportunity for trade expansion with 19 out of 45 countries in the scope of this paper.
\end{abstract}

Key words: climate smart goods (CSG), gravity model, trade potential, Vietnam

\section{Introduction}

The linkage between economic growth and environmental degradation has been well discussed in a large body of literature. Indeed, economic growth has always been the prior development goal in many countries with an objective of making progress in people's living standards. However, the rapid increase in per capita income is also associated with negative effects on global environment. It is clear from scientific evidence that rapid internationalization of production and service activities is attributed to sharp expansion of fossil fuel-intensive production and cargo transportation (Mathur, 2014), leading to increasing global greenhouse gas (GHG) emissions into the atmosphere. Consequently, the fast growth in economic activities accelerates climate change and its impacts. Since the implementation of open door policy initiated in 1986, Vietnam has made a transition from a centrally planned economy to a market-oriented system with remarkable achievements, characterized by high economic growth and strong economic integra- tion (Dang, et al., 2013). Nevertheless, environmental degradation and climate change are emerging as key challenges facing Vietnam to maintain its rapid economic growth in a sustainable manner (ADB, 2013).

Climate change is manifested by significant variation in the measurement of climate, for instance, temperature or precipitation lasting for an extended period of time (Dinda, 2014). According to the Intergovernmental Panel on Climate Change (IPCC) Fourth assessment report in 2007, during the period 1906-2005 the average global temperature witnessed an increase by $0.740 \mathrm{C}$ and it is expected to increase by $0.20 \mathrm{C}$ every decade. In Vietnam, over the past 50 years (1958-2007), the annual average temperature increased by 0.5 to $0.70 \mathrm{C}$ and sea level also experienced an increase by about $20 \mathrm{~cm}$ (MONRE, 2009). Truly, climate change that seriously affects life, environment and all economic activities all over the world is one of the toughest threats facing human beings in the $21^{\text {st }}$ century. World Bank (2008) shows that even though less developed countries are responsible for negligible or little effect on climate change; they suffer from the

\footnotetext{
A Faculty of International Business and Economics, University of Economics and Business, Vietnam National University, Hanoi, Vietnam

* Corresponding author: Nguyen Anh Thu, e-mail: thuna@vnu.edu.vn
} 
hardest impacts of climate change. Also, due to low level of economic development, these countries have the weakest capacity to adapt to those impacts. Indeed, climate change in Vietnam is recognized to be extremely serious and is emerging as a huge challenge to the achievements of sustainable development goal (MONRE, 2009). In this respect, Vietnamese government has adopted many responding action plans and other initiatives with an attempt to reduce emissions and improve energy efficiency. For instance, the national strategy on climate change approved in 2011 targets at 20,000-22,000 MW of hydroelectric power generation by 2020 . In addition, the project plans to raise the contribution of new and recycled energies to commercial energies to $5 \%$ by 2020 .

The increasing awareness of climate change and environmental issues both in Vietnam and other countries in the world has resulted in ever higher levels of environmental regulations. Truly, the stringent ordinance towards environmental protection leads to growing market and trade opportunity for climate smart goods which tend to have no, minimum or less adverse impacts on the environment. Definitely, promoting the exchange and dissemination of those goods and technologies improves the energy efficiency and reduces the environmental deterioration. Also, it is clear that trade liberalization helps countries get access to CSG if they are not able to produce those products efficiently locally. Dinda (2014) indicates that through free and liberalized trade, exporters may have incentives to create new products and technologies that release less GHG emissions. In addition, the previous studies all agree that climate change truly provides opportunity to redesign all economic activities (Dinda, 2014), especially for developing countries. According to World Bank (2008), while developed countries are now the major players in trading of CSG, a few developing ones play major role in global exports of climate smart products. The less developed countries, therefore, should focus on the production and trade of CSG. It is only by shifting towards cleaner technologies and climate smart products that those countries including Vietnam can develop with less pollution and GHG emissions.

The growing concerns about environmental degradation and climate change have encouraged increasing number of studies on trade of environmental goods as well as CSG. In Vietnam, most of those papers, however, approach the climate change from the technical point of view and technological solutions towards mitigating climate change impacts. In addition, there has been a research gap with limited number of studies examining Vietnam's trade of climate smart goods which contribute to mitigating climate change. This paper, therefore, investigates the trade potential of CSG in Vietnam to answer the main question "Whether Vietnam has fully realized its potential in trading of CSG?". For the purposes of this paper, the gravity model is employed to estimate the determinants explaining Vietnam's trade performance in climate smart products. Besides, the estimated equation and the method using speed of convergence are utilized to calculate trade potential of CSG.

The paper is organized as follows - Literature review- second Section provides the theoretical framework and background reviews; Third section describes data and research methodology; Fourth Section presents the estimation results and discussion on the determinants explaining trade in those goods, and the calculation of trade potential for CSG. The last section summarizes the research findings.

\section{Literature review}

\section{Definitions}

\section{Climate change}

IPCC (2007) defines climate change as "a change in the state of the climate that can be identified (e.g., by using statistical tests) by changes in the mean and/or the variability of its properties, and that persists for an extended period, typically decades or longer". Over the past decades, human activities have been attributed to release large amounts of carbon dioxide $\left(\mathrm{CO}_{2}\right)$ and greenhouse gases (Dinda, 2014), causing significant changes in atmospheric composition. Indeed, traditional economic activities mainly depend on consumption of fossil fuels which are the primary causes of generating global greenhouse gases (GHG). Furthermore, deforestation, industrial processes and other agricultural activities contribute to increasing GHG emissions (Dinda, 2014). Consequently, over the period 1800 to 2012, the average temperature of land and ocean surface increased by 0.85 [0.65-1.06] ${ }^{\circ} \mathrm{C}$ (IPCC 2014, p.40). Indeed, even small variations in the average global temperature may lead to tremendous changes in climate and weather (Dinda, 2014). A lot of countries all over the world have been witnessing considerable changes in precipitation or melting snow and ice, resulting in hard droughts and more floods than ever. The next generation will be extremely vulnerable to climate change impacts. Therefore, reducing GHG emissions plays a vital role in mitigating its impacts.

\section{Environmental goods and services}

The term "environmental goods and services" (EGS) has been well discussed in the literature. However, there is no generally agreed definition of EGS due to the fact that environmental issues that affect the view- 
points on the coverage of EGS vary in different countries all over the world (Jha, 2008, p.1). A group of scholars from OECD and Eurostat firstly introduced the explanation of EGS in the 1990s as follows: "The environmental goods and services industry consists of activities which produce goods and services to measure, prevent, limit, minimize or correct environmental damage to water, air and soil, as well as problems related to waste, noise and ecosystems. This includes cleaner technologies, products and services that reduce environmental risk and minimize pollution and resource use". According to Dinda (2014) environmental goods can be defined as "equipment, material, or technology used to address a particular environmental problem or as a product that is itself environmentally preferable to other similar products because of its relatively benign impact on the environment". In addition, those provided by ecosystems or activities of human beings to help addressing environmental issues and minimizing environmental deterioration and protecting the biosphere of Earth are environmental services (Dinda, 2014).

\section{Climate smart goods (CSG)}

CSG which are part of the group environmental goods and services (EGS) can be referred as "products, components, and technologies that tend to have a relatively less adverse impact on the environment" (Dinda, 2014). UNESCAP (2011) introduces a list of 64 goods as a single group "CSG", which establishes low carbon growth technologies. For instance, one of the subcategories includes clean coal technology which contributes to energy efficiency and helps reducing environmental degradation. Another subcategory of CSG known as wind technology containing three integral components such as gear box, coupling, and wind turbine concentrates on generating wind power. According to Mathur (2014), wind power and turbine production has been witnessing a strong growth in recent years and is now one of the most widely used types of climate smart technologies. In general, promoting trade and production or consumption of CSG, which release no or minimum GHG and less negative impacts on environment, plays an important role in implementing technological transformation strategies which are necessary for mitigating climate change impacts.

In particular, World Trade Organization (WTO) proposes a list of 153 environmental goods at 6 digit HS codes. Out of those 153 goods, World Bank (WB) introduces a list of 43 products including a wide range of products from wind turbines to solar panels to water saving shower. In addition, UNESCAP also proposes an additional 21 products that appeared on one of the recent ICTSD lists (Renewables and Buildings) and also on the APEC, OECD or WTO list. In this respect, various studies including Mathur (2014), Mathur (2012),
Dinda (2014), have recently defined 64 climate smart products at 6 digit HS code (2002) based on the proposed lists of various international organizations including WB, ICTSD, WTO, APEC, UNESCAP.

\section{Review of related literature}

In recent years, considerable attention has been devoted to studies on climate smart goods and green technology trade. A number of researchers have highlighted the worsening signs of climate change due to increasing GHG emission. Therefore, promoting trade and investments of CSG plays an essential role in mitigating the impacts of climate change. In this respect, most of the previous studies have attempted to answer the questions "Is there any trade opportunity for CSG products in climate change?". The typical papers include the empirical analysis of CSG trade of Ecuador by Mathur (2014); the estimation of potential trade gap in climate smart components in Asia by Dinda (2014); the study on climate smart goods and technology in Asia-Pacific region conducted by UNESCAP (2011). Additionally, Van Son \& Kalirajan (2013) measure India's export potential in environment goods. In general, with the growing concerns about environmental issues and climate change, a lot of studies have been carried out with an attempt to promote trade of CSG which tend to have less adverse impacts on the environment. Noticeably, gravity model has been widely used to measure the trade potential of CSG. In addition, impacts of free and liberalized trade in CSG are also popularly examined in order to provide or make such goods available for countries of which domestic markets are unable to produce them efficiently, such as Mathur (2014), Dinda (2014).

Gravity model has been commonly used to assess the trade policy implications and particularly, recently, for analyzing the effects of free trade agreements (FTAs) on the trade flows. Among a number of studies applying the gravity model in international trade, many scholars focus on predicting the trade potentials and examining determinants affecting trade relations, such as Batra (2006), Rahman (2003), Chritie (2002), Do Tri Thai (2006), Jafari et al. (2011), Dinh Thi Thanh Binh et al. (2011). In addition, gravity model has been extensively used to analyze the effects of FTAs using the dummy variables that allow to identify the bloc effects on both intra-bloc and extra-bloc trade. Aitken (1973) and Winters (1987) are the pioneers in this field. Other noticeable studies include Guilhot (2010), Sudsawasd (2012), Urata and Okabe (2007), Nguyen Anh Thu, Vu Van Trung and Le Thi Thanh Xuan (2015), and Nguyen Anh Thu (2012). To sum up, gravity model is actually a practical tool for estimating trade volumes and examining the explanatory factors and policy implication on them. Therefore, it has been popularly used in many studies to 
measure impacts of FTAs that have been signed and have come into effect. Besides, the gravity equation can be employed to predict the trade potential, from which policy implication may be drawn out about the potential trading partners signing FTAs in the future.

\section{Overview of Vietnam's trade of CSG}

Over the last decades, the increasing awareness of climate change and environmental issues has encouraged many countries to promote production and consumption of CSG. The world trade value of climate smart products has been rising over the years. However, its contribution to total trade remained relatively stable over the years and did not exceed 3\% according to UN Comtrade statistics. Vietnam is not an exception to that trend. Indeed, a number of studies have highlighted the worsening signs of climate change in Vietnam. Also, Vietnamese government has attempted to pursue consumption of environmental goods and services as well as CSG and environmental friendly production. However, Vietnam's environmental industry is highly disorganized and in the early stage of development. According to surveys conducted by Ministry of Natural Resources and Environment, there are 4,000 enterprises working in the field of environmental services, most of which are small and medium sized.

Figure 1 reveals that the value of Vietnam's exported CSG rose dramatically from 0.15 billion USD in 2004 to 1.84 billion USD in 2013, with the annual average growth rate of $34.41 \%$. Similarly, import value of these goods increased significantly from 627 million USD in 2004 to about 4.71 billion USD in 2013, with the impressive average growth rate of $82.36 \%$ annually. However, while the export value is rather limited, Vi- etnam has been a net importer of CSG over the past years. In addition, the share of CSG in total trade of Vietnam remained relatively flat and did not exceed $3 \%$. In particular, its contribution to total trade fluctuated from $0.76 \%$ to $2.82 \%$ and remained quietly stable during the period 2004-2013.

According to UN Comtrade statistics, East Asia is an important market of CSG for Vietnam. Meanwhile, the US is the largest importing partner, accounting for $18.48 \%$ of the total value of CSG export in 2013, followed by Japan and Saudi Arabia. In 2013, Vietnam imported about 1.93 billion USD of climate smart products from China, accounting for $40.98 \%$ of the total value of imported CSG. In other words, China is the biggest supplier of Vietnam for these commodities, followed by the Republic of Korea and Japan with the import value of 0.87 and 0.59 billion USD respectively. In the main, China, Japan, the Republic of Korea and the US are the major trading partners of Vietnam with regard to climate smart components. In addition, ASEAN is also an important partner of CSG trade, which accounts for around $11.20 \%$ of trade value of CSG in 2013 .

\section{Research methodology}

\section{Gravity model}

\section{Model specification}

Gravity model which is based on Newton's universal law of gravitation in physics has been extensively used to examine the determinants affecting trade among countries. The model was firstly applied by Tinbergen (1962) and many other researchers followed to develop a diverse range econometric model of bilateral

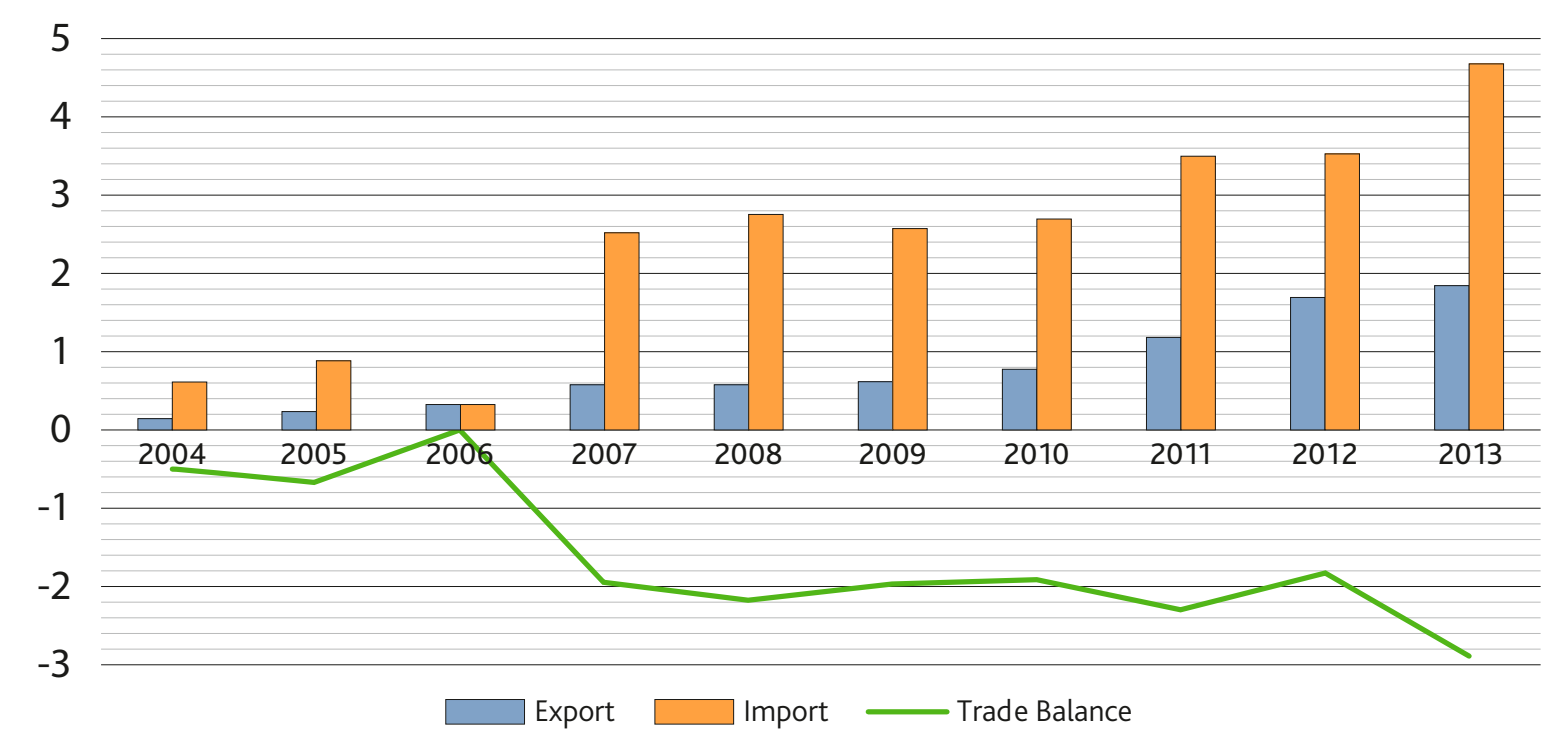

Figure 1. Vietnam's trade value of CSG from 2004 to 2013 (unit: billion USD)

Source: UN Comtrade database 
trade flows. In general, the basic idea of gravity model is that the volume of trade between two countries has a positive relation with the economic size of both countries but negative correlation with the geographic distance between them. Distance can be embodied in physical, political, cultural and linguistic dimensions.

However, the model was criticized for lacking theoretical underpinnings. Since the late 1970s, further developments of the gravity model were made to fill the theoretical gap (For example, Anderson 1979, Bergstrand 1985; Helpman 1987; Deardorff 1984). Truly, the introduction of theoretical gravity by these authors has significantly increased the popularity of the model in empirical study.

Therefore, the gravity model employed within this paper for estimation and analysis purposes is considered as the following equation, in which all continuous variables are expressed in logarithms:

$$
\begin{gathered}
\operatorname{LnT}_{\mathrm{ij}}{ }^{\mathrm{t}}=\mathrm{a}_{\mathrm{ij}}+\mathrm{a}_{1} \operatorname{lnGDP}_{\mathrm{i}}{ }^{\mathrm{t}}+\mathrm{a}_{2} \ln _{\operatorname{lnOP}}{ }_{\mathrm{i}}^{\mathrm{t}}+ \\
\mathrm{a}_{3} \ln \operatorname{DISTANCE}_{\mathrm{ij}}+\mathrm{a}_{4} \operatorname{lnREER}_{\mathrm{ij}}{ }^{\mathrm{t}}+\mathrm{a}_{5} \operatorname{lnINFR}_{\mathrm{i}}{ }^{\mathrm{t}}+ \\
\mathrm{a}_{6} \operatorname{lnINFR}_{\mathrm{j}}{ }^{\mathrm{t}}+\mathrm{a}_{7} \mathrm{BORDER}_{\mathrm{ij}}+\mathrm{a}_{8} \operatorname{TA}_{\mathrm{ij}}+\mathrm{e}_{\mathrm{ij}}^{\mathrm{t}}(\mathrm{1})
\end{gathered}
$$

In which:

$\mathrm{i}=1,2, \ldots ., 45$ (partner countries); $(\mathrm{j})=1$ (Vietnam); $(\mathrm{t})$

implies years from 2002 to 2013 ;

$\mathrm{e}_{\mathrm{ij}}{ }^{\mathrm{t}}$ :error term

$\mathrm{T}_{\mathrm{ij}}{ }^{\mathrm{t}}$ denotes country (i) trade value in CSG with country $(\mathrm{j})$ in year $(\mathrm{t})$.

$\mathrm{GDP}_{\mathrm{i}}{ }^{\mathrm{t}}$ and $\mathrm{POP}_{\mathrm{i}}{ }^{\mathrm{t}}$ describe the gross domestic product (GDP) and population of country (i) in year $t$, respectively.

DISTANCE $_{\mathrm{ij}}$ measure the geographic distance between country (i) and country (j).

$\mathrm{REER}_{\mathrm{ij}}{ }^{\mathrm{t}}$ is the real effective exchange rate between country (i) and country $(j)$ in year $(t)$.

$\mathrm{INFR}_{i}{ }^{t}$ and $\mathrm{INFR}_{j}{ }^{\mathrm{t}}$ indicate the quality of infrastructure score index of country (i) and country (j) in year $(\mathrm{t})$, respectively.

$\mathrm{BORDER}_{\mathrm{ij}}$ is the dummy variable for common border, which take the value of 1 if the two countries share the same border and o otherwise.

$\mathrm{TA}_{\mathrm{ij}}$ represents the dummy variable, which is equal to 1 if country (i) has the trade agreement with Vietnam, otherwise 0 .

\section{Data}

This study mainly follows UNESCAP (2011), Mathur (2014) and Dinda (2014) to identify the list of 64 CSG products under the six-digit HS code (2002). The list was introduced and chosen from WB, ICTS, WTO, APEC, Dinda (2014) and Mathur (2012). In this respect, this study examines $64 \mathrm{CSG}^{1}$ as one category

1 For detailed descriptions of 64 CSG, please see UNESCAP (2011) for the estimation and analysis purposes. According to World Bank (2008), these 64 CSG comprise four groups of climate-smart energy technologies: clean coal technologies (containing HS code 840510, 841181 and 841182); energy-efficient lighting (HS code 853931); and two RETs - wind power generation technologies (HS code 848340 and 848360 ) and solar photovoltaic systems (HS code 850720,853710 and 854140 ). The last category referred as "other codes" consists of all HS codes not mentioned in the four groups above.

Concerning the data source, Vietnam's trade data on CSG which equals the value of export plus import to and from 45 trading partners was taken from the UN Comtrade database (http://comtrade.un.org/). These 45 countries are the main trading partners in CSG of Vietnam, which account for about $90 \%$ of trade volume in climate smart products. GDP is obtained from World Bank database. All data are expressed in US dollars. Data on population are collected from the World Development Indicators database. Real exchange rate is taken from the research of Darvas, Zsolt (2012). Data on distance and border employed within this research are drawn from web Centre d' Etudes Prospectives et d'Informations Internationales (CEPII) (http://www.cepii.fr/). The distance is geographic distance between the biggest cities of Vietnam and its trading partners. The quality of infrastructure scores of both Vietnam and its partners are taken from the Global Competitiveness Report released annually by World Economic Forum. This index covers the quality of transport and communications infrastructure network. General infrastructure in the country is ranked for all selected countries in this paper, ranging from 1 for underdeveloped to 7 for extensive and efficient ones. Trade agreement participation including both multilateral and bilateral ones is collected from the website of the Ministry of Industry and Trade of Vietnam.

\section{Trade potential}

Gravity model has been extensively used to calculate trade potential. For example, Maurel and Cheikbossian (1998) and Montanari (2005) employ the estimated equation to measure the trade potential predicted from the gravity model. Accordingly, the trade value predicted will be compared with the actual trade value to answer the research question whether bilateral trade between two particular countries has fully reached the potential. This method of calculating trade potential, however, has recently been criticized for lacking theoretical underpinnings. In particular, Egger (2002) explains the difference between trade potential and actual trade value as an indicator of the model misspecification. In this regard, Jakab et al. (2001) firstly introduces the method using the speed of 
convergence (SC) to calculate trade potential. The formula for calculating SC is expressed as follows:

$\mathrm{SC}=\frac{\text { Average growth rate of potential trade }}{\text { Average growth rate of actual trade }} \cdot 100-100$

If the average growth rate of potential trade is lower than that of actual trade, SC will be negative, indicating the convergence. On the contrary, the positive value of SC shows the divergence of trade. According to Do Tri Thai (2006), estimated results obtained from this method are more reliable than the analysis of point estimates due to its exploitation of the dynamic structure of the data during this estimation.

However, Dinh Thi Thanh Binh et al. (2011) shows that the negative sign of the speed of convergence cannot capture the convergence of potential and actual trade. Therefore, following the methodology of previous studies, this paper applies both the method using the speed of convergence and the point estimates as follows:

\section{$\Delta \mathrm{T}=$ potential trade value - actual trade value}

For our analysis, in particular, we denote convergence if $\mathrm{SC}$ and $\Delta \mathrm{T}$ turn out with the opposite signs, and we posit divergence in the opposite case. Countries with the result of convergence indicate that Vietnam has unexploited trade potential or there is a high opportunity for trade expansion in the future. In contrast, the remaining partners with the result of divergence denote the situation of over exploited trade potential.

\section{Results and discussion}

\section{Determinants of Vietnam's trade of CSG}

Based on data properties and test results, random effect model (REM) is the best method for estimation. This paper, therefore, focuses on the results obtained from REM for estimation and analysis purposes.

Overall, R-squared value of 0.6993 means that the dependent variables explain approximately $70 \%$ variations of trade values of CSG between Vietnam and its 45 trading partners. This seems like a high value due to the diversity of the units in the sample, indicating that the model fits data relatively well.

The coefficient of GDP is positive at $1 \%$ significant level. Accordingly, Vietnam's trade of CSG is positively correlated with the economic size of its trading partners. Larger economies tend to have higher demand for importing CSG from Vietnam. Also, the increase in GDP reveals that these countries are able to produce larger amount of CSG for exports to
Table 1. Estimated results using random effects regression

\begin{tabular}{|c|c|c|c|}
\hline \multicolumn{4}{|c|}{ Dependent variable: $\operatorname{LnTRADE}_{\mathrm{ijt}}$} \\
\hline Explanatory variable & Coefficients & Std. Err. & P-value \\
\hline $\operatorname{LnGDP}_{i t}$ & $1.862^{* * *}$ & 0.136 & 0.000 \\
\hline $\operatorname{LnPOP}_{i t}$ & $-0.491^{* * *}$ & 0.133 & 0.000 \\
\hline LnDISTANCE $_{\mathrm{ij}}$ & $-1.738^{* * *}$ & 0.323 & 0.000 \\
\hline $\ln R E E R_{i j t}$ & $-1.404^{* * *}$ & 0.411 & 0.001 \\
\hline LnINFR $_{\text {it }}$ & $-0.828^{*}$ & 0.457 & 0.071 \\
\hline LnINFR $_{\text {jt }}$ & $2.180 * * *$ & 0.465 & 0.000 \\
\hline Border $_{\mathrm{ij}}$ & $1.586^{* *}$ & 0.702 & 0.024 \\
\hline $\mathrm{TA}_{\mathrm{ij}}$ & 0.373 & 0.538 & 0.488 \\
\hline _cons & -11.888 & 2.921 & 0.000 \\
\hline \multicolumn{4}{|c|}{$\begin{array}{l}\text { Total panel (balanced) observations: } 540 \\
\text { R-squared overall }=0.6993\end{array}$} \\
\hline \multicolumn{4}{|c|}{$\begin{array}{l}* * *, * *, * \text { denote the statistical significance at } 1 \% ; 5 \% \text { and } \\
10 \% \text { levels, respectively }\end{array}$} \\
\hline
\end{tabular}

Source: author's calculation in STATA

Vietnam. This positive relation is in line with previous studies on Environmental Kuznets Curve which states that higher income increases the demand for climate smart components and cleaner technologies. Accordingly, larger economies mean higher investment in cleaner technology development, better infrastructure system for adopting those technologies. Foreign market size, however, negatively influences trade in CSG. This negative correlation can be explained by the fact that as population grows, the trading partners may substitute the demand for export or import by internal trade.

Geographic distance is another explanatory variable which is statistically significant at $1 \%$ level. The negative sign of estimated coefficient for this variable follows the basic hypothesis of gravity model. In particular, $1.73 \%$ increase in Vietnam's trade of CSG is explained when the transportation cost decreases by $1 \%$. Furthermore, Vietnam tends to trade more CSG with neighbouring countries, which is evident by the positive value of border coefficient. Over the years, the advance in transportation technologies has reduced the transportation cost and promoted the exchange of goods among countries. However, the distance between the countries still remains a major determinant in Vietnam's trade of CSG.

Real effective exchange rate captures the impacts of price variations due to exchange rate volatility on trade flows of CSG. The estimation shows that exchange rate variable is significant at $1 \%$ level with negative sign. This negative correlation is in line with previous studies which tested the impacts of exchange rate on bilateral trade, such as Dell' Aricaca (1999), Do Tri Thai (2006). In particular, the appreciation of Vietnam Dong against the currencies of trading partners 
results in an increase in import value and a reduction in the export value in CSG of Vietnam. The negative impact on total trade can be explained by the fact that Vietnam's exports of CSG are labour intensive while its imports are capital-intensive climate components. Therefore, Vietnam's exports of these products are more sensitive to price variations than its imports. In this regard, the former effect on export will dominate the bilateral trade between Vietnam and 45 countries of CSG. As a result, an increase in exchange rate leads to a decrease in trade value of climate smart products. An increase by $1 \%$ in exchange rate which means Vietnam Dong appreciation will reduce total trade in CSG of Vietnam by $1.4 \%$. The estimated coefficient value also reveals that price competitiveness has a huge impact on trade variation. Therefore, the management of exchange rate plays a major role in promoting trade of CSG especially with regard to the fact that Vietnam is a net importer of those goods.

The coefficient of dummy variable for trade agreement is found to be statistically insignificant in this regression. TAij is hypothesized to turn out with positive sign because the reduction in tariff and non-tariff barriers within those agreements is expected to promote trade of CSG. However, Vietnam's accession to a lot of FTAs in the period 2002-2013 has thus far not been shown to have impact on trade of CSG of Vietnam. This may be explained by observing the actual trade performance of Vietnam. For example, Vietnam has not signed any free trade agreements with the US and Saudi Arabia but the value of Vietnam's export of climate smart products to the US and Saudi Arabia accounted for $18.48 \%$ and $10.18 \%$ of the total CSG exports in 2013, respectively. This finding is in line with many other previous papers including $\mathrm{Ma}$ thur (2012), Mathur (2014) and Van Son, N., \& Kalirajan, K. (2013) which point out the weak impacts of tariff reduction on trade of climate smart products. In addition, the result obtained within this research is a particular case in CSG trade, which supports the inefficiency of Vietnam's participation in a number of multilateral and bilateral trade agreements over the last decades.

Finally, the last two variables reflecting the quality of infrastructure of Vietnam and its trading partners are found to be positive and negative, respectively. The overall infrastructure scores included in the model reflect the efficiency and extensiveness of road, airport, port and telecommunication, and the time required for customs clearance. Estimation indicates that quality of infrastructure of both Vietnam and its partners are important determinants of Vietnam's trade performance in CSG. In particular, $1 \%$ improvement in this score of Vietnam and 45 countries leads to $2.18 \%$ increase and $0.83 \%$ decrease in total trade val- ue of CSG of Vietnam, respectively. Also, it is clear that the improvement of Vietnam's infrastructure index has a relatively larger impact on trade compared to that of the partners. The efficiency of infrastructure system helps to reduce production costs and transportation costs. Additionally, a well-developed infrastructure system is essential for attracting FDI inflow in cleaner technologies and production which are crucial for promoting trade of climate smart products of Vietnam. Therefore, a better infrastructure is not only strongly associated with the expansion of CSG trade but also with Vietnam's trade in other commodities and economic growth in general.

However, it is interesting to observe that distance reflecting the transportation and other trade costs remains as an important determinant of Vietnam's trade of CSG when the quality of infrastructure is included in the model. Indeed, the efficiency and extensiveness of infrastructure help reducing trade costs. According to Nordås \& Piermartini (2004), the reduction in trade costs due to efficiency improvement of infrastructure predominantly increase the trade value of CSG, while distance is also an important determinant for the distribution of increased trade value of CSG among trading partners.

\section{Trade potential of CSG for Vietnam}

Considering only statistically significant coefficients, the estimated trade of CSG for Vietnam is as follows:

$$
\begin{gathered}
\mathrm{LnT}_{\mathrm{ijt}}=-11.888+1.862^{\star} \operatorname{lnGDP} \mathrm{P}_{\mathrm{it}}-0.491^{\star} \ln \mathrm{POP}_{\mathrm{it}} \\
-1.738^{\star} \ln \operatorname{lnISTANCE}_{\mathrm{ij}}-1.404^{\star} \operatorname{lnEER}_{\mathrm{ijt}}-0.828 \\
\ln ^{\star} \mathrm{INFR}_{\mathrm{it}}+2.18 \mathrm{o} \ln ^{\star} \mathrm{INFR}_{\mathrm{jt}}+1.586^{\star} \text { Border }_{\mathrm{ij}}(2)
\end{gathered}
$$

The regression results from equation (2) are employed to estimate the speed of convergence (SC) and the difference between potential and actual trade value of CSG $(\Delta T)$. The calculation of trade potential of CSG products of Vietnam is presented in Table 2. The bilateral trade situations in CSG between Vietnam and its 45 trading partners are divided into two separate groups including convergence and divergence. Trade opportunity of CSG denoted by convergence situation implies that there is a scope to increase $\mathrm{Vi}$ etnam's trade value of climate smart products with its particular partners. The total predicted trade of CSG in 2013 was approximately 10.95 billion USD while the actual trade of CSG was about 6.55 billion USD. Therefore, Vietnam could have increased trade by 4.4 billion USD which is the trade potential value of CSG.

Considering both SC and $\Delta \mathrm{T}$ for each particular market, this study is able to identify that Vietnam had the convergence with 19 out of 45 countries in the scope of the research for this paper. In this regard, Vietnam has not exploited full potentials in trading 
of CSG with 19 countries. In other words, there is a large scope for trade expansion between Vietnam and those countries in the next period.

Concerning trade situation with major trading partners of CSG, Vietnam has strong trade opportunity with China, the US and Japan. However, the trade of CSG with Hong Kong (China) and the Republic of Korea is over exploited according to Table 2. ASEAN countries, except for Laos witness the divergence situation in trading of CSG with Vietnam. This may be explained by the fact that Vietnam shares the same advantage in low labour and production cost with ASEAN members. Therefore, trade liberalization makes ASEAN market more competitive with regard to CSG. Generally, it is obvious from empirical findings that Vietnam would not gain more when liberalizing trade of CSG with ASEAN due to increasing competitiveness and trade divergence situation. For the remaining countries in Asia-Pacific region, Vietnam has still huge potential trade of CSG with the Russian Federation, India, Australia, New Zealand, Israel and Bangladesh. In general, for most countries in Asia-Pacific region except for ASEAN, Vietnam has untapped trade opportunity of CSG. Definitely, it suggests that Vietnam should explore this potential trade and focus on trading of CSG within this dynamic region.

In addition, the potential trading partners in the EU include Austria, Spain, Greece, Norway, Ireland, Germany and Sweden. These are the markets with high opportunity for trade expansion in terms of climate smart components.

In summary, the gravity model is not only useful for investigating the determinants of trade in climate smart products but it is also able to quantify the trade opportunity in those goods. Accordingly, China, Japan and the US are the most important partners which Vietnam should explore to realize its full potential of trading of CSG.

Table 2. Trade potential in CSG between Vietnam and its trading partners in 2013

\begin{tabular}{|c|c|c|c|c|}
\hline Country & Group & $\begin{array}{l}\text { Speed of convergence } \\
\text { (SC) }\end{array}$ & $\begin{array}{l}\text { Difference between potential } \\
\text { and actual trade }(\Delta T) \text { (USD) }\end{array}$ & Situation* \\
\hline China & 1 & -19.25 & $4,775,532,312$ & 1 \\
\hline Japan & 1 & -1.63 & $367,840,985$ & 1 \\
\hline Hong Kong (China) & 1 & 5.76 & $148,178,593$ & 0 \\
\hline United States & 1 & -51.36 & $73,207,026$ & 1 \\
\hline Korea, Rep. & 1 & -43.51 & $-669,259,551$ & 0 \\
\hline Indonesia & II & 2.06 & $112,372,868$ & 0 \\
\hline Malaysia & II & 39.84 & $31,553,482$ & 0 \\
\hline Thailand & II & 3.40 & $17,911,018$ & 0 \\
\hline Singapore & II & 84.98 & $6,814,140$ & 0 \\
\hline Lao PDR & II & -60.76 & $3,911,856$ & 1 \\
\hline Philippines & II & -33.77 & $-101,683,152$ & 0 \\
\hline Cambodia & II & -33.86 & $-25,628,858$ & 0 \\
\hline Brunei & II & -90.93 & $2,562,796$ & 1 \\
\hline Austria & III & -19.41 & $5,663,621$ & 1 \\
\hline France & III & 40.46 & $72,670,800$ & 0 \\
\hline United Kingdom & III & 14.87 & $53,639,826$ & 0 \\
\hline Spain & III & -35.92 & $24,147,373$ & 1 \\
\hline Greece & III & -75.90 & $4,274,107$ & 1 \\
\hline Norway & III & -87.07 & $3,595,207$ & 1 \\
\hline Ireland & III & -56.11 & $3,569,913$ & 1 \\
\hline Germany & III & 73.20 & $-886,048$ & 1 \\
\hline Switzerland & III & -72.40 & $-901,128$ & 0 \\
\hline Slovak Republic & III & -56.44 & $-1,319,062$ & 0 \\
\hline Finland & III & -63.77 & $-1,322,254$ & 0 \\
\hline Sweden & III & 19.50 & $-2,060,520$ & 1 \\
\hline Turkey & III & -91.25 & $-2,716,318$ & 0 \\
\hline Ukraine & III & -32.22 & $-3,243,137$ & 0 \\
\hline Denmark & III & -54.13 & $-5,550,100$ & 0 \\
\hline Belgium & III & -89.85 & $-9,022,064$ & 0 \\
\hline
\end{tabular}




\begin{tabular}{|l|c|c|c|c|}
\hline Country & Group & $\begin{array}{c}\text { Speed of convergence } \\
\text { (SC) }\end{array}$ & $\begin{array}{c}\text { Difference between potential } \\
\text { and actual trade ( } \Delta \text { T) (USD) }\end{array}$ & Situation* \\
\hline Poland & III & -98.30 & $-9,919,327$ & 0 \\
\hline Czech Republic & III & -81.37 & $-10,418,057$ & 0 \\
\hline Italy & III & -30.89 & $-26,123,731$ & 0 \\
\hline Netherlands & III & -84.17 & $-74,303,627$ & 1 \\
\hline Canada & IV & -53.86 & $20,118,541$ & 0 \\
\hline Argentina & IV & -71.91 & $-4,196,840$ & 0 \\
\hline Chile & IV & -88.47 & $-5,539,982$ & 1 \\
\hline Mexico & IV & -97.65 & $3,275,808$ & 0 \\
\hline Brazil & IV & -90.30 & $-10,546,634$ & 1 \\
\hline Russian Federation & V & -46.15 & $49,310,596$ & 1 \\
\hline India & V & -69.71 & $28,786,681$ & 1 \\
\hline Australia & V & -58.74 & $61,454,985$ & 1 \\
\hline New Zealand & V & -93.51 & $2,196,6377$ & 1 \\
\hline Israel & V & -62.66 & $20,118,541$ & 1 \\
\hline Bangladesh & V & -88.34 & 611,810 & 0 \\
\hline Saudi Arabia & V & -93.16 & $-161,104,722$ & \\
\hline
\end{tabular}

*Note: 1 and 0 denote convergence, divergence respectively. Group I includes the main trading partners of CSC of Vietnam, Group II includes ASEAN countries, Group III includes members of the European Union, Group IV includes Canada and Latin American countries, Group V includes other countries in Asia-Pacific region.

Source: Author's calculation

\section{Conclusion}

By applying the gravity model for bilateral trade data of climate smart goods between Vietnam and 45 trading partners in the period 2002-2013, this paper identifies the main factors explaining trade of CSG including economic size, market size of partner countries, distance, real exchange rate, border, the quality of infrastructure of both Vietnam and its partners. In addition, the estimated equation and the method of speed of convergence are utilized to measure trade potential of CSG for Vietnam. Accordingly, there is a huge room for trade expansion with 19 out of 45 trading partners in the scope of this paper. In general, this paper contributes to the empirical measurement of trade potential of climate smart components and identifies the markets with high opportunity for further development. Therefore, there appears to be a great urgency for Vietnam to pursue environmental friendly production and consumption of climate smart goods which not only will contribute to economic growth but also will reduce the impacts of climate change and environmental degradation.

\section{References}

Aitken, N.D. 1973. The effect of the EEC and EFTA on European trade: A temporal cross-section analysis, The American Economic Review 63-5, 881-892.

Anderson, J.E. 1979. A Theoretical Foundation for the Gravity Equation, American Economic Review 691, 106-116.
Asian Development Bank (ADB) 2013. Vietnam environment and climate change assessment. Mandaluyong City, Philippines.

Batra, A. 2006. India's global trade potential: The gravity model approach. Global Economic Review 35-3, 327-361.

Bergstrand, J.H. 1985. The Gravity Equation in International Trade: Some Microeconomic Foundations and Empirical Evidence. Review of Economics and Statistics 67-3, 474-481.

Christie, E. 2002. Potential trade in South-East Europe: a gravity model approach, SEER-South-East Europe Review for Labour and Social Affairs 4, 81-101.

Dang, V., Do, T., Nguyen, C., Phung, T., Phung, T. 2013. Economic Development, Inequality and Climate Change in Vietnam. MPRA paper No. 54190, Online at http://mpra.ub.uni-muenchen.de/5419o/.

Darvas, Z. 2012. Real effective exchange rates for 178 countries: a new database. Bruegel Working Paper 2012/06, 15 March 2012.

Deardorff, A.V. 1984. Testing Trade Theories and Predicting Trade Flows, In R. W.Jones and P. B. Kenen, eds. Handbook of International Economics. 1st ed 1, 467-517. New York: North-Holland.

Dell' Ariccia, G. 1999. Exchange rate fluctuation and trade flows: evidence from European Union. IMF Staff papers 46-3.

Dinda, S. 2014. Climate Change and Trade Opportunity in Climate Smart Goods in Asia: Application of Gravity Model. The International Trade Journal 28-3, 264-28o. 
Dinh Thi Thanh Binh, Nguyen Viet Duong and Hoang Manh Cuong. 2011. Applying Gravity Model to Analyze Trade Activities of Vietnam.

Do Tri Thai, 2006. A gravity model for trade between Vietnam and twenty-three European countries. Unpublished Doctorate Thesis, Department of Economics and Society, Högskolan Dalarna, 14.

Egger, P. 2002. An econometric view on the estimation of gravity models and the calculation of trade potentials. World Economy 25-2, 297-312.

Guilhot, L. 2010. Assessing the impact of the main East-Asian free trade agreements using a gravity model. First results. Economics Bulletin 30-1, 282291.

Helpman, E. 1987. Imperfect Competition and International Trade: Evidence from Fourteen Industrial Countries. Journal of the Japanese and International Economies 1-1, 62-81.

IPCC. 2007. Climate Change 2007: impacts, adaptation and vulnerability: contribution of Working Group II to the fourth assessment report of the Intergovernmental Panel on Climate Change (Vol. 4). Cambridge University Press.

IPCC. 2014. Climate Change 2014: Synthesis Report, Contribution of Working Groups I, II and III to the Fifth Assessment Report of the Intergovernmental Panel on Climate Change. IPCC, Geneva, Switzerland.

Jafari, Y., Ismail, M. A., Kouhestani, M.S. 2011. Determinants of Trade Flows among D8 Countries: Evidence from the Gravity Model. Journal of Economic Cooperation and Development 32-3, 21-38.

Jakab, Z.M., Kovács, M.A., Oszlay, A. 2001. How far has trade integration advanced?: An analysis of the actual and potential trade of three Central and Eastern European countries. Journal of Comparative Economics 29-2, 276-292.

Jha, V. 2008. Environmental priorities and trade policy for environmental goods: a reality check. ICTSD International Centre for Trade and Sustainable Development.

Mathur, S.K. 2012. Trade of CSG by ESCAP Member Nations: A Gravity Analysis. Journal of International Economics 3-2, 0976-0792.

Mathur, S.K. 2014. Trade in Climate Smart Goods of Ecuador: Quantitative Analysis Using Trade Indi- ces, SMART and Gravity Analysis. European Scientific Journal 10-10, 158-183.

Maurel, M., Cheikbossian, G. 1998. The new geography of Eastern European trade. Kyklos 51-1, 45-72.

Ministry of Natural Resources and Environment (MONRE) 2009. Climate Change, Sea Level Rise Scenarios for Viet Nam. Hanoi, Vietnam.

Montanari, M. 2005. EU trade with Balkans, large room for growth?. Eastern European Economics 43$1,59-81$.

Nordås, H.K., Piermartini, R. 2004. Infrastructure and trade.

Nguyen Anh Thu, 2012. Assessing the Impact of Vietnam's Integration under AFTA and VJEPA on Vietnam's Trade Flows, Gravity Model Approach. Yokohama Journal of Social Sciences 17-2, 137-148.

Nguyen Anh Thu, Vu Van Trung, Le Thi Thanh Xuan 2015. Assessing the Impact of ASEAN+3 Free Trade Agreements on ASEAN's Trade Flows: A Gravity Model Approach. Mediterranean Journal of Social Sciences 6-6, 395-401.

Rahman, M.M. 2003. A Panel Data Analysis of Bangladesh's Trade: The Gravity Model Approach. University of Sydney, September 11-13-2003.

Sudsawasd, S.S. 2012. Trade Integration in East Asia: An Empirical Assessment. Modern Economy 3-3, 319-329.

Tinbergen, J. 1962. Shaping the World Economy: Suggestions for an International Economic Policy. New York: The Twentieth Century Fund.

UNESCAP 2011. Climate-smart trade and investment in Asia and the Pacific. United Nations, New York, 2011.

Urata, S. Okabe, M. 2007. The impacts of free trade agreements on trade flows: An application of the gravity model approach. RIETE Discussion Paper Series 07-E-052.

Van Son, N., Kalirajan, K. 2013. Export of Environmental Goods: India's Potential and Constraints. The Australian National University, Australia South Asia Research Centre.

Winters, L.A. 1987. Britain in Europe: A survey of quantitative trade studies. Journal of Common Market Studies 25-4, 315-336.

World Bank 2008. International trade and climate change: economic, legal, and institutional perspectives. Washington, DC: Oxford University Press. 
Trade Potential of Climate Smart Goods of Vietnam:

An Application of Gravity Model

Appendix 1.

List of 45 partner countries in the gravity model

\begin{tabular}{|l|l|}
\hline Region & Countries \\
\hline East Asia & $\begin{array}{l}\text { 9 ASEAN countries (except for Myanmar), } \\
\text { China, Japan, Republic of Korea, Hong Kong } \\
\text { (China) }\end{array}$ \\
\hline $\begin{array}{l}\text { European } \\
\text { Union }\end{array}$ & $\begin{array}{l}\text { Austria, France, United Kingdom, Spain, } \\
\text { Greece, Norway, Ireland, Germany, } \\
\text { Switzerland, Slovak Republic, Finland, } \\
\text { Sweden, Turkey, Ukraine, Denmark, Belgium, } \\
\text { Poland, Czech Republic, Italy, Netherlands }\end{array}$ \\
\hline America & Canada, Argentina, Chile, Mexico, Brazil \\
\hline Oceania & Australia, New Zealand \\
\hline Others & $\begin{array}{l}\text { Russia Federation, India, Israel, Bangladesh, } \\
\text { Saudi Arabia }\end{array}$ \\
\hline
\end{tabular}

Appendix 2.

Breusch-Pagan Lagrangian multiplier test for random effects

\begin{tabular}{|c|c|c|}
\hline \multicolumn{3}{|c|}{$\operatorname{LnTRADE}[i d, \mathrm{t}]=\mathrm{Xb}+\mathrm{u}[\mathrm{id}]+\mathrm{e}[\mathrm{id}, \mathrm{t}]$} \\
\hline \multicolumn{3}{|c|}{ Estimated results: } \\
\hline & Var & Sd $=$ Sqrt (Var) \\
\hline LnTRADE & 5.709377 & 2.38943 \\
\hline e & 0.8064182 & 0.8980079 \\
\hline u & 0.8717641 & 0.9336831 \\
\hline \multicolumn{3}{|c|}{ Test: $\operatorname{Var}(\mathrm{u})=0$} \\
\hline \multicolumn{3}{|c|}{$\operatorname{Chi} 2(01)=642.50$} \\
\hline \multicolumn{3}{|c|}{ Prob $>$ Chi2 $=0.0000$} \\
\hline
\end{tabular}

Source: Author's calculation in STATA

Note: Myanmar is excluded in observation because data is not available

\section{Appendix 3.}

Hausman test for random and fixed effects

\begin{tabular}{|c|c|c|c|c|}
\hline & \multicolumn{4}{|c|}{ Coefficients } \\
\hline & $\begin{array}{l}\text { (b) } \\
\text { Fixed }\end{array}$ & $\begin{array}{c}\text { (B) } \\
\text { Random }\end{array}$ & $\begin{array}{c}(\mathrm{b}-\mathrm{B}) \\
\text { Difference }\end{array}$ & $\begin{array}{c}\text { Sqrt }\left(\operatorname{diag}\left(V_{-} b-V_{-} B\right)\right. \\
\text { S.E. }\end{array}$ \\
\hline LnGDPit & 1.939909 & 1.862157 & 0.077752 & 0.154988 \\
\hline LnPOPit & 2.401597 & -0.49167 & 2.893274 & 1.662025 \\
\hline LnREER & -1.400247 & -1.404101 & 0.003854 & 0.109079 \\
\hline LnINFRit & -0.888381 & -0.828064 & -0.060316 & 0.245396 \\
\hline LnINFRjt & 1.363982 & 2.180363 & -0.816380 & 0.366716 \\
\hline \multicolumn{5}{|c|}{$\mathrm{b}=$ consistent under $\mathrm{Ho}$ and $\mathrm{Ha}$; obtained from $x$ treg } \\
\hline \multicolumn{5}{|c|}{$\mathrm{B}=$ inconsistent under $\mathrm{Ha}$, efficient under $\mathrm{Ho}$; obtained from xtreg } \\
\hline \multicolumn{5}{|c|}{ Test: Ho: difference in coefficients not systematic } \\
\hline \multicolumn{5}{|c|}{$\operatorname{Chi2}(5)=(b-B)^{\prime}\left[\left(V_{-} b-V_{-} B\right)^{\wedge}(-1)\right](b-B)=15.42$} \\
\hline \multicolumn{5}{|c|}{ Prob $>$ chi2 $=0.0874$} \\
\hline \multicolumn{5}{|c|}{ (V_b-V_B is not positive definite) } \\
\hline
\end{tabular}

Source: Author's calculation in STATA 